\title{
Ionotropic NMDA Receptor Signaling Is Required for the Induction of Long-Term Depression in the Mouse Hippocampal CA1 Region
}

\author{
Walter E. Babiec, ${ }^{1 \star}$ Ryan Guglietta, ${ }^{2 \star}$ Shekib A. Jami, ${ }^{3}$ Wade Morishita, ${ }^{5}$ Robert C. Malenka, ${ }^{5}$ and Thomas J. 0'Dell ${ }^{1,4}$ \\ ${ }^{1}$ Department of Physiology, David Geffen School of Medicine, ${ }^{2}$ Interdepartmental Ph.D. Program for Neuroscience, ${ }^{3}$ Molecular, Cellular, and Integrative \\ Physiology Ph.D. Program, and 4UCLA Integrative Center for Learning and Memory, University of California Los Angeles, Los Angeles, California 90095-1751, and \\ ${ }^{5}$ Nancy Pritzker Laboratory, Department of Psychiatry and Behavioral Sciences, Stanford University School of Medicine, Palo Alto, California 94304
}

Previous studies have provided strong support for the notion that NMDAR-mediated increases in postsynaptic Ca ${ }^{2+}$ have a crucial role in the induction of long-term depression (LTD). This view has recently been challenged, however, by findings suggesting that LTD induction is instead attributable to an ion channel-independent, metabotropic form of NMDAR signaling. Thus, to explore the role of ionotropic versus metabotropic NMDAR signaling in LTD, we examined the effects of varying extracellular $\mathrm{Ca}^{2+}$ levels or blocking NMDAR channel ion fluxes with MK-801 on LTD and NMDAR signaling in the mouse hippocampal CA1 region. We find that the induction of LTD in the adult hippocampus is highly sensitive to extracellular $\mathrm{Ca}^{2+}$ levels and that MK-801 blocks NMDAR-dependent LTD in the hippocampus of both adult and immature mice. Moreover, MK-801 inhibits NMDAR-mediated activation of p38-MAPK and dephosphorylation of AMPAR GluA1 subunits at sites implicated in LTD. Thus, our results indicate that the induction of LTD in the hippocampal CA1 region is dependent on ionotropic, rather than metabotropic, NMDAR signaling.

Key words: hippocampus; long-term depression; MK-801; NMDA receptor

\section{Introduction}

Excitatory synapses in many brain regions undergo long-lasting, activity-dependent changes in synaptic strength. For example, increases in intracellular $\mathrm{Ca}^{2+}$ mediated by NMDAR activation during brief periods of high-frequency synaptic activity induces long-term potentiation (LTP), a long-lasting enhancement of synaptic strength (Lüscher and Malenka, 2012). In contrast, long-term depression (LTD), a persistent decrease in synaptic strength, is induced by periods of low-frequency synaptic activity. Although activation of G-protein-coupled metabotropic glutamate receptors (mGluRs) can induce LTD, at many synapses the induction of LTD is dependent on NMDAR activation and increases in intracellular $\mathrm{Ca}^{2+}$ (Collingridge et al., 2010).

The notion that $\mathrm{Ca}^{2+}$ signaling has a crucial role in NMDARdependent forms of synaptic plasticity is widely accepted. How-

Received Dec. 28, 2013; revised March 4, 2014; accepted March 7, 2014.

Author contributions: W.E.B., R.G., S.A.J., W.M., R.C.M., and T.J.O. designed research; W.E.B., R.G., S.A.J., W.M., and T.J.O. performed research; W.E.B., R.G., S.A.J., W.M., and T.J.0. analyzed data;W.E.B., R.M., and T.J.0. wrote the paper.

This work was supported by grants from the National Institute of Mental Health (T.J.O. and R.C.M.). W.E.B. was supported by Grant T32NS007101 from the National Institute of Neurological Disorders and Stroke, and S.J. was supported by Grant T32GM065823-11 from the National Institute of General Medical Sciences.

*W.E.B. and R.G. contributed equally to this work.

The authors declare no competing financial interests.

Correspondence should be addressed to Dr. T. J. O'Dell, Department of Physiology, David Geffen School of Medicine at UCLA, 53-231 Center for the Health Sciences, Box 951751, Los Angeles, CA 90095-1751. E-mail: todell@mednet.ucla.edu.

DOI:10.1523/JNEUROSCI.5419-13.2014

Copyright $\odot 2014$ the authors $\quad 0270-6474 / 14 / 345285-06 \$ 15.00 / 0$ ever, although the induction of LTD is blocked by competitive NMDAR antagonists (Dudek and Bear, 1992; Mulkey and Malenka, 1992), a recent study found that LTD is not inhibited by MK-801, an uncompetitive antagonist that blocks NMDAR channels (Nabavi et al., 2013). This suggests that LTD involves a metabotropic form of NMDAR signaling where, in a manner similar to mGluR signaling, conformational changes in NMDARs induced by glutamate binding can directly activate downstream signaling pathways. Interestingly, the NMDARdependent inhibition of excitatory synaptic transmission induced by amyloid- $\beta$ (A $\beta$ ) peptides is also MK-801 insensitive, suggesting that NMDAR metabotropic signaling contributes to A $\beta$-induced synaptic dysfunction in Alzheimer's disease (Kessels et al., 2013; Tamburri et al., 2013). In addition, metabotropic NMDAR signaling may mediate activation of p38-MAPK (Nabavi et al., 2013), a protein kinase implicated in both LTD (Zhu et al., 2002) and the synaptotoxic effects of $A \beta$ peptides ( $\mathrm{Li}$ et al., 2011; Chen et al., 2013).

NMDAR-mediated ionotropic signaling undergoes pronounced changes during early postnatal development, in part because of developmental changes in the expression of different GluN2-type NMDAR subunits (Paoletti et al., 2013). Whether metabotropic signaling by NMDARs is also developmentally regulated is unclear, however. To examine this question, we compared the effects of MK-801 on LTD induction and NMDAinduced changes in protein phosphorylation in hippocampal slices obtained from young and adult mice. We find that MK-801 blocks LTD in the hippocampal CA1 region of adult and, surpris- 
A

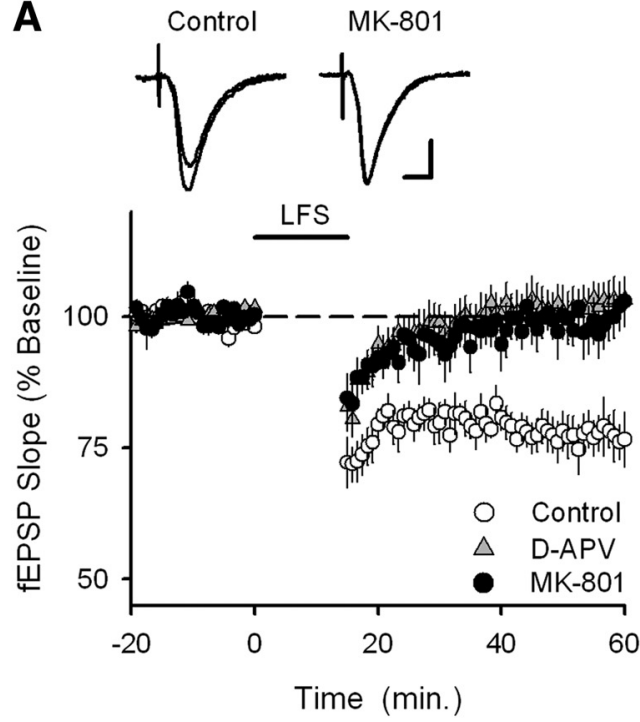

D
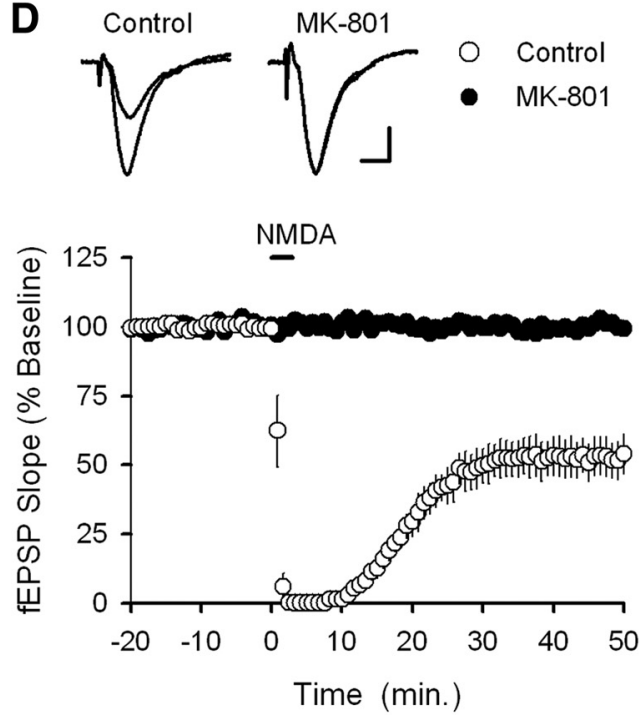

B

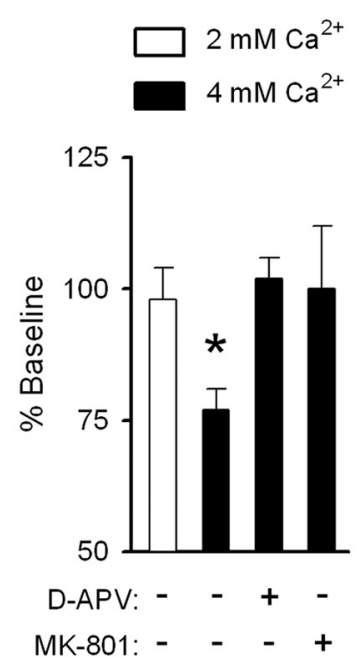

C

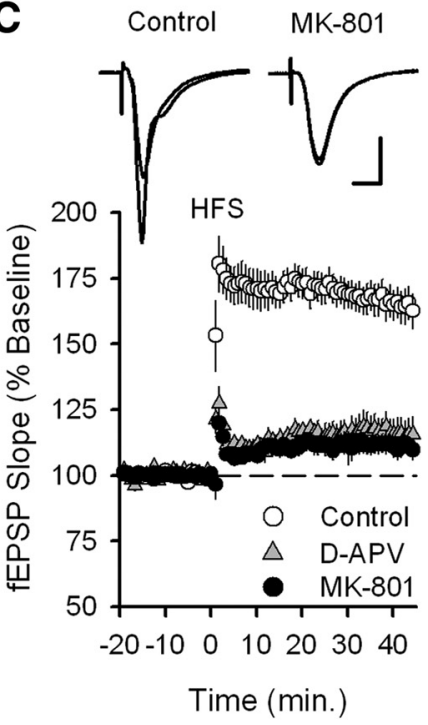

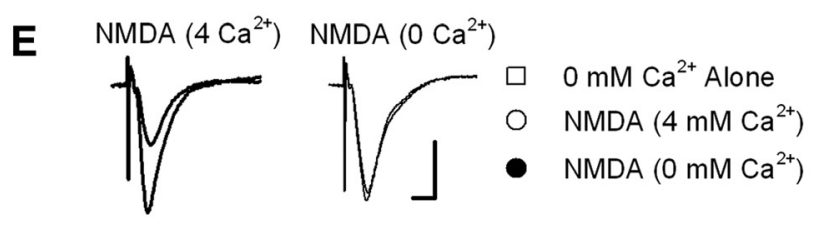

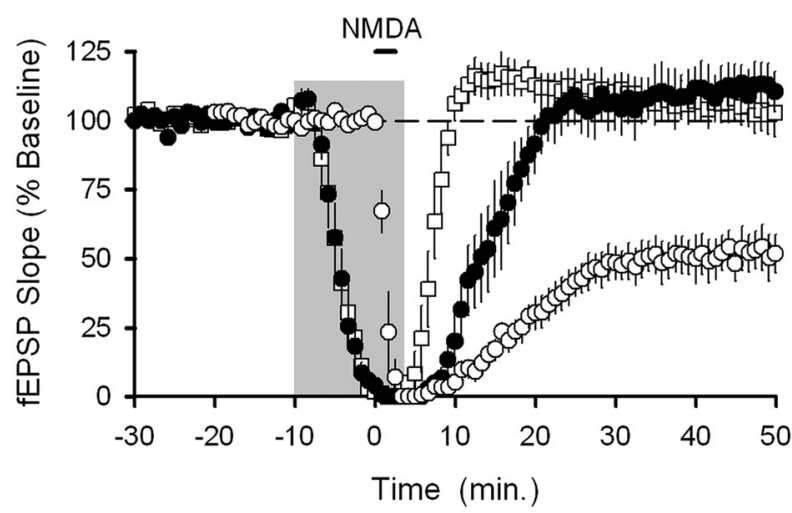

Figure 1. MK-801 blocks LTD in the hippocampal CA1 region of adult mice. A, LTD induced by 1 Hz LFS (open circles, $n=6$ ) is blocked by $10 \mu \mathrm{m} \mathrm{MK-801} \mathrm{(filled} \mathrm{circles,} n=8$ ) or $50 \mu \mathrm{m} \mathrm{D-APV}$ (triangles, $n=6$ ). MK-801 or D-APV was present throughout the experiment. Traces are superimposed fEPSPs recorded during baseline and 45 min after LFS. $B$, Changes in synaptic strength induced by LFS in slices bathed in ACSF containing $2 \mathrm{~mm} \mathrm{CaCl}_{2}$ (open bar, $n=8$ ) or $4 \mathrm{~mm} \mathrm{CalCl}$ (filled bars, ${ }^{*} p<0.005$ compared with pre-LFS baseline)., , HFS-induced LTP (open circles, $n=9$ ) is inhibited by MK-801 (filled circles, $n=8$ ) or D-APV (triangles, $n=6$ ). Traces show superimposed fEPSPs recorded during baseline and 45 min after HFS. D, chem-LTD is blocked by MK-801. Bath application of $20 \mu \mathrm{M}$ NMDA induced LTD in interleaved control experiments (open circles, $n=6$ ) but had no effect on synaptic strength in MK-801-treated slices (filled circles, $n=4, p<0.001$ compared with control). Traces are superimposed fEPSPs recorded during baseline and $50 \mathrm{~min}$ after NMDA application. $\boldsymbol{E}$, chem-LTD is blocked when NMDA is applied in $\mathrm{Ca}^{2+}$-free $\mathrm{ACSF}$ (no added CaCl ${ }_{2}$ ). A 15 min bath application of $\mathrm{Ca}^{2+}$-free ACSF alone (shaded region) transiently abolished synaptic transmission but had no lasting effect on synaptic strength (squares, $n=8$ ). Bath application of NMDA

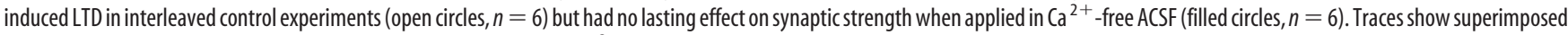
fEPSPs recorded during baseline and $50 \mathrm{~min}$ after NMDA application in $\mathrm{Ca}^{2+}$-free ACSF (right) in control experiments (left). Calibration: $A, D, E, 1 \mathrm{mV}, 5 \mathrm{~ms} ; C, 2 \mathrm{mV}, 5 \mathrm{~ms}$.

ingly, young mice. Moreover, LTD induction in the adult hippocampus is highly sensitive to extracellular $\mathrm{Ca}^{2+}$ levels. Thus, ionotropic, rather than metabotropic, NMDAR signaling is responsible for the induction of LTD during postnatal development and in the mature hippocampus.

\section{Materials and Methods}

Slice preparation and extracellular recording. Standard methods approved by the University of California, Los Angeles (UCLA) and Stanford University Institutional Animal Care and Use Committees were used to prepare $400-\mu \mathrm{m}$-thick hippocampal slices. In experiments done at UCLA, slices were obtained from adult (8-12 weeks old, male) or young (14-21 $\mathrm{d}$ old, male or female) $\mathrm{C} 57 \mathrm{BL} / 6 \mathrm{~N}$ mice and maintained $\left(\right.$ at $30^{\circ} \mathrm{C}$ ) in interface-type chambers perfused $(2-3 \mathrm{ml} / \mathrm{min})$ with oxygenated $(95 \%$
$\mathrm{O}_{2} / 5 \% \mathrm{CO}_{2}$ ) ACSF containing (in $\mathrm{mm}$ ) $124 \mathrm{NaCl}, 4 \mathrm{KCl}, 25 \mathrm{NaHCO}_{3}, 1$ $\mathrm{NaH}_{2} \mathrm{PO}_{4}, 2 \mathrm{CaCl}_{2}, 1.2 \mathrm{MgSO}_{4}$, and 10 glucose. Slices were allowed to recover for $\geq 2 \mathrm{~h}$ before an experiment, and fEPSPs evoked by Schaffer collateral/commissural fiber stimulation in the CA1 region were recorded using techniques described previously (Delgado et al., 2007). Because of the use-dependent nature of the blockade of NMDARs by MK-801 (Huettner and Bean, 1988), slices were exposed to ACSF containing MK-801 (10 $\mu \mathrm{M})$ for $\geq 2 \mathrm{~h}$ before the start of an experiment, and MK-801 was present throughout the experiment. To facilitate the induction of LTD in slices from adult mice, the extracellular concentration of $\mathrm{Ca}^{2+}$ was increased to $4 \mathrm{~mm}$ (Norris et al., 1996; Delgado et al., 2007).

In experiments done at Stanford, hippocampal slices obtained from CD1 mice (18-21 d old, male or female) were prepared in a similar manner to $\mathrm{C} 57 \mathrm{BL} / 6 \mathrm{~N}$ mice. Slices ( $300 \mu \mathrm{m}$ thick) were allowed to re- 

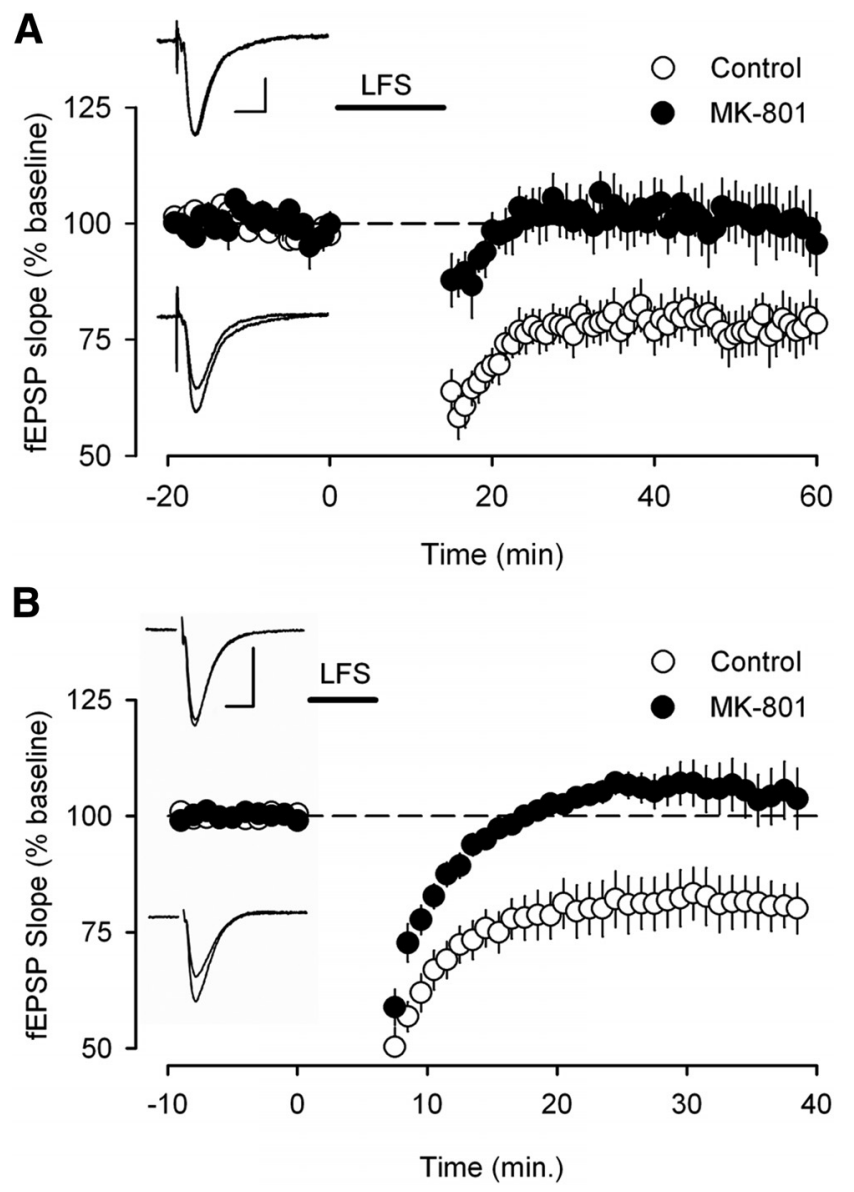

Figure 2. MK-801 blocks LTD induction in the hippocampal CA1 region of slices from young animals. A, MK-801 blocks $1 \mathrm{~Hz}$ LFS-induced LTD in slices from young C57BL/6 mice (open circles, interleaved control experiments, $n=7$; filled circles, LFS in $10 \mu \mathrm{M}$ MK-801, $n=6, p<$ 0.05 compared with control). $\boldsymbol{B}$, MK-801 blocks $2 \mathrm{~Hz}$ LFS-induced LTD in slices obtained from young CD1 mice. Slices were incubated in ACSF containing $50 \mu \mathrm{m}$ MK- 801 for $2-6 \mathrm{~h}$ before $2 \mathrm{~Hz}$ LFS, and MK-801 was washed out after LFS (filled symbols, $n=8, p<0.05$ compared with control). Open symbols indicate results from interleaved control experiments $(n=8)$. Traces in $\boldsymbol{A}$ and $\boldsymbol{B}$ show superimposed fEPSPs recorded during baseline and after LFS in control (bottom) and MK-801 (top) experiments. Calibration: $\boldsymbol{A}, 1 \mathrm{mV}, 10 \mathrm{~ms} ; \boldsymbol{B}, 0.5 \mathrm{mV}, 10 \mathrm{~ms}$.

cover in oxygenated $\left(95 \% \mathrm{O}_{2} / 5 \% \mathrm{CO}_{2}\right)$ ACSF maintained at $30^{\circ} \mathrm{C}$ for $1 \mathrm{~h}$ and transferred to a holding chamber containing ACSF or ACSF with MK-801 $(50 \mu \mathrm{M})$ at room temperature for a minimum of $2 \mathrm{~h}$ before being transferred to the recording chamber $\left(\right.$ at $\left.30^{\circ} \mathrm{C}\right)$. To maximize the number of synaptic NMDARs blocked by MK-801, slices were prestimulated at $0.2 \mathrm{~Hz}$ for $5 \mathrm{~min}$ at approximately twice the intensity used to elicit baseline fEPSPs. Picrotoxin $(50 \mu \mathrm{M})$ was present in the perfusion solution in all experiments.

Three different synaptic stimulation protocols were used to examine the effect of MK-801 on activity-dependent changes in synaptic strength: (1) $1 \mathrm{~Hz}$ low-frequency stimulation (LFS; 900 pulses); (2) $2 \mathrm{~Hz}$ LFS (900 pulses); and (3) high-frequency stimulation (HFS; four trains of $100 \mathrm{~Hz}$ stimulation, $1 \mathrm{~s}$ in duration; inter-train interval, $20 \mathrm{~s}$ ). We also examined the effect of MK-801 on LTD using a chemical induction protocol (chem-LTD; Lee et al., 1998; Delgado et al., 2007). In these experiments, slices were maintained in a submerged-slice recording chamber, and LTD was induced by a $3 \mathrm{~min}$ bath application of $20 \mu \mathrm{M}$ NMDA.

Western immunoblotting. Hippocampal slices or CA1 mini slices (where CA3 and dentate gyrus were removed during dissection to isolate the CA1 region) were prepared and maintained as described above. Slices were then placed into two separate interface-type chambers and allowed to recover for $2 \mathrm{~h}$. During this time, one chamber was perfused with ACSF, whereas slices in the second chamber were exposed to ACSF con- taining $10 \mu \mathrm{M}$ MK-801. Several slices from both chambers were then collected to serve as untreated controls, and the remaining slices were collected immediately after a $3 \mathrm{~min}$ bath application of $20 \mu \mathrm{M}$ NMDA. Slice homogenates were prepared using techniques described previously (Delgado et al., 2007), and proteins were resolved on 12\% SDS-PAGE gels and transferred onto nitrocellulose membranes. After incubation in primary and secondary antibodies, immunoreactive bands were visualized using enhanced chemiluminesence. For quantification, all blots were probed with anti-tubulin antibodies, and the optical density of bands of interest were normalized to tubulin levels in each lane to control for variations in loading.

Reagents and antibodies. NMDA (Sigma-Aldrich) and MK-801 and D-APV (both from Abcam) were prepared as concentrated stock solutions in double-distilled $\mathrm{H}_{2} \mathrm{O}$. Anti-phospho-Thr840 GluA1 (1:2000) and total GluA1 (1:4000) antibodies were from Abcam. Anti-phosphoSer845 GluA1 (1:1000) was from Millipore. Anti-phospho-p38-MAPK (1:1000) antibody was from Cell Signaling Technology. Anti- $\beta$ IIItubulin (1:20,000) was from Sigma-Aldrich. HRP-conjugated secondary antibodies (1:2000) were obtained from GE Healthcare.

Statistics. All results are presented as mean \pm SEM. Statistical significance was determined using paired and unpaired $t$ tests, one-way ANOVAs, or, where appropriate, one-way ANOVAs on ranks. Student-Newman-Keuls tests were used for post hoc comparisons.

\section{Results}

MK-801 blocks LTD and LTP in hippocampal slices from adult mice

Blocking NMDAR ionotropic signaling with MK-801 provides a useful approach for examining ion channel-independent, metabotropic forms of NMDAR signaling (Yang et al., 2004; Kessels et al., 2013; Nabavi et al., 2013; Tamburri et al., 2013). Thus, to determine whether metabotropic NMDAR signaling underlies LTD in the CA1 region of the adult hippocampus, we first examined whether MK-801 fails to inhibit LTD induced by $1 \mathrm{~Hz}$ LFS in slices obtained from 8- to 12-week-old mice. In control experiments, fEPSPs were depressed to $77 \pm 4 \%$ of baseline $45 \mathrm{~min}$ after LFS ( $n=6 ; p<0.005$ compared with pre-LFS baseline; Fig. $1 A$ ). In contrast, LFS in the presence of the competitive NMDAR antagonist D-APV had no lasting effect on synaptic strength (fEPSPs were $102 \pm 4 \%$ of baseline, $n=6$ ), indicating that the induction of LTD is NMDAR dependent (Fig. 1A). LTD was also blocked, however, in slices where LFS was delivered in the presence of MK-801 (10 $\mu$ M; Fig. $1 A$; fEPSPs were $100 \pm 12 \%$ of baseline, $n=$ 8). Consistent with previous reports (Norris et al., 1996; Delgado et al., 2007), the induction of LTD in slices from adult animals was sensitive to extracellular $\mathrm{Ca}^{2+}$ levels as LTD was not induced by LFS in slices bathed in ACSF containing $2 \mathrm{mM} \mathrm{CaCl}_{2}$ (Fig. $1 B$ ). Thus, $\mathrm{Ca}^{2+}$-dependent, ionotropic NMDAR signaling is required for the induction of LTD in the hippocampal CA1 region of adult mice.

In the CA1 region of hippocampal slices from young animals, HFS in the presence of MK-801 induces LTD (Nabavi et al., 2013). Thus, we also examined the effect of MK-801 on HFSinduced changes in synaptic strength in slices from adult mice. Although MK-801 significantly inhibited HFS-induced LTP, it did not enable the induction of LTD [Fig. $1 C$; 45 min post-HFS fEPSPs were $164 \pm 6 \%$ of baseline in control experiments $(n=9)$ and were $111 \pm 4 \%$ of baseline in MK-801 experiments $(n=8)$; $p<0.001$ compared with control]. The small potentiation of synaptic transmission induced by HFS in the presence of MK-801 was also seen in experiments where NMDARs were blocked with D-APV (Fig. 1C). Together, these data suggest that the HFS protocol used in these experiments induces a small NMDARindependent form of potentiation and that blocking NMDAR 
channels with MK-801 does not enable HFS-induced LTD in slices from adult mice.

As a final test for the potential role of metabotropic NMDAR signaling in LTD in the adult hippocampus, we examined whether chem-LTD can still be induced in the presence of MK-801. Although a 3 min bath application of $20 \mu \mathrm{M}$ NMDA induced significant LTD in control experiments (fEPSPs were $52 \pm 7 \%$ of baseline 50 min after NMDA application, $n=6$ ), NMDA had no effect on synaptic transmission in slices incubated in ACSF containing MK-801 (Fig. 1D; fEPSPs were $101 \pm 1 \%$ of baseline, $n=4 ; p<0.001$ compared with control). Thus, like LFSinduced LTD, chem-LTD is also dependent on ionotropic NMDAR signaling. Indeed, bath application of NMDA in $\mathrm{Ca}^{2+}$-free ACSF failed to induce LTD [Fig. 1E; 50 min post-NMDA application in $\mathrm{Ca}^{2+}$-free ACSF fEPSPs was $112 \pm 8 \%$ of baseline $(n=6)$ compared with $53 \pm$ $8 \%$ of baseline in interleaved control experiments $(n=6) ; p<0.001]$.

\section{MK-801 blocks LTD in hippocampal} slices from young mice

Because MK-801 readily blocked LTD in hippocampal slices from adult animals, we reexamined the effects of MK-801 on LTD induction in slices obtained from young mice to test whether LTD is MK801 insensitive in the hippocampus of young animals (Nabavi et al., 2013). Surprisingly, MK-801 completely blocked LFS-induced LTD in slices obtained from young C57BL/6 mice Fig. $2 A$; fEPSPs were $78 \pm 5 \%$ of baseline $50 \mathrm{~min}$ after LFS in interleaved control experiments $(n=7)$ but were $99 \pm 6 \%$ of baseline after LFS in the presence of MK-801 $(n=6) ; p<0.05$ compared with control). Similarly, MK801 also blocked LTD induced by a different LFS protocol (900 pulses at $2 \mathrm{~Hz}$ ) in slices obtained from young CD1 mice Fig. $2 B$; fEPSPs were $104 \pm 6 \%$ of baseline after LFS in MK-801 $(n=8)$ compared with $81 \pm 5 \%$ of baseline in interleaved control experiments $(n=8) ; p<0.05$. Thus, as in adult animals, our results indicate that NMDAR channel ion flux is crucial for inducing LTD in the hippocampal CA1 region of young mice.

\section{MK-801 blocks NMDAR-mediated} changes in protein phosphorylation at sites implicated in LTD

Because dephosphorylation of AMPAR GluA1 subunits and activation of p38-MAPK are thought to contribute to LTD induction (Lee et al., 1998, 2000; Zhu et al., 2002; Delgado et al., 2007), we also used MK-801 to examine whether metabotropic signaling

\section{A Adult}
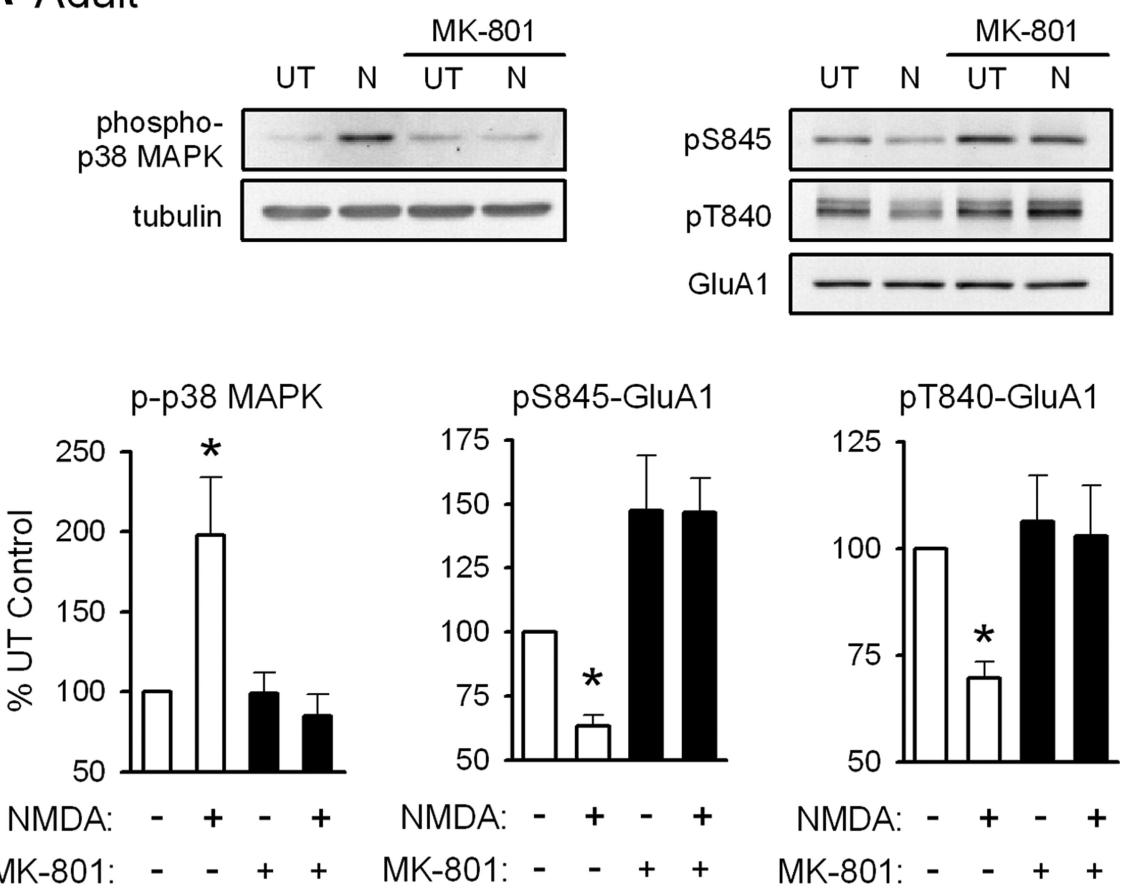

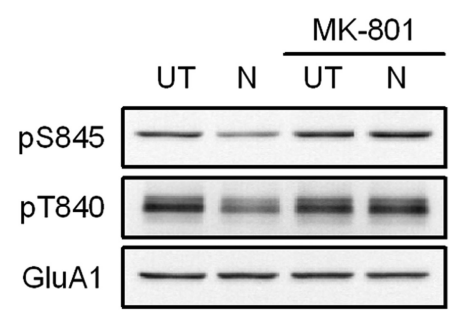

p-p38 MAPK

pS845-GluA1
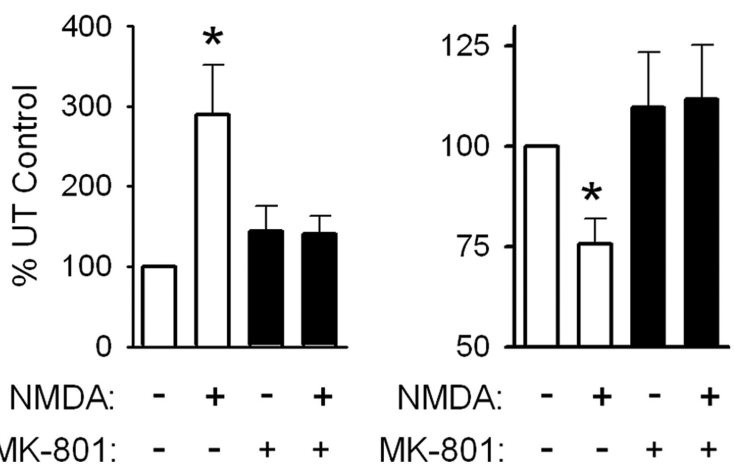

pT840-GluA1

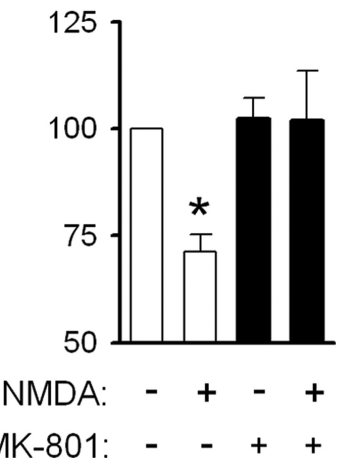

Figure 3. MK-801 blocks activation of p38-MAPK and AMPAR GluA1 subunit dephosphorylation induced by NMDAR activation. $\boldsymbol{A}$, MK-801 blocks NMDA-induced increases in p38-MAPK phosphorylation and GluA1 dephosphorylation at serine 845 and threonine 840 in CA1 mini slices from adult mice $\left(\left[\mathrm{Ca}^{2+}\right]_{0}=4.0 \mathrm{~mm}, n=6\right)$. Although basal levels of GluA1 S845 phosphorylation tended to be elevated in MK-801-treated slices, this difference was not statistically significant $(p=$ 0.065). UT, Untreated slices; N, NMDA treated slices. $B$, NMDA-induced increases in p38-MAPK phosphorylation and GluA1 phosphorylation are blocked by MK-801 in hippocampal slices from young mice $\left(\left[\mathrm{Ca}^{2+}\right]_{0}=2.0 \mathrm{~mm}, n=5\right) .{ }^{*} p<0.05$ compared with untreated control slices.

by NMDARs regulates p38-MAPK and GluA1 phosphorylation. Although a 3 min application of $20 \mu \mathrm{M}$ NMDA induced a nearly twofold increase in p38-MAPK phosphorylation in control CA1 mini slices from adult mice, it had no effect on p38-MAPK phosphorylation in mini slices incubated in ACSF containing MK-801 
(Fig. 3A). NMDA-induced increases in p38-MAPK phosphorylation in slices from young mice were also blocked by MK-801 (Fig. 3B). Similarly, MK-801 blocked NMDA-induced dephosphorylation of GluA1 subunits in slices from adult (Fig. 3A) and young (Fig. $3 B$ ) mice. Thus, ionotropic NMDAR signaling is required for activation of downstream signaling pathways implicated in LTD in the hippocampus of young and adult mice.

\section{Discussion}

Within the postsynaptic density of excitatory synapses, NMDARs are associated with a large number of adaptor proteins and downstream signaling molecules through protein interactions mediated by the C-terminal tails of their GluN2 subunits (Husi et al., 2000; Paoletti et al., 2013). These protein interactions might provide a mechanism whereby conformational changes associated with glutamate binding could activate downstream signaling pathways. Thus, the notion that NMDARs are capable of metabotropic-like signaling is an intriguing possibility. Moreover, kainate receptors, another type of ionotropic glutamate receptor, are capable of metabotropic signaling (Lerma and Marques, 2013). However, until recently, there have been only a few reports suggesting that NMDARs might be capable of metabotropic signaling (Vissel et al., 2001; Yang et al., 2004). Thus, the recent suggestion that a $\mathrm{Ca}^{2+}$-independent, metabotropic form of signaling by NMDARs underlies the induction of LTD represents a potentially important advance in our understanding of both synaptic plasticity and NMDAR signaling (Nabavi et al., 2013). However, in contrast to these findings, we find that the induction of LTD is sensitive to extracellular $\mathrm{Ca}^{2+}$ levels and that blocking NMDAR channels with MK-801 blocks LTD. MK-801 also abolished activation of p38-MAPK and changes in AMPAR GluA1 subunit phosphorylation induced by NMDAR activation. Thus, our results are consistent with the view that $\mathrm{Ca}^{2+}$-dependent, ionotropic NMDAR signaling underlies the induction of LTD at Schaffer collateral fiber synapses onto CA1 pyramidal cells in both the adult and young hippocampus.

The reasons for the discrepancy between our findings and those reported by Nabavi et al. (2013) are unclear. Because of the use-dependent nature of the MK-801 block of NMDAR channels (Huettner and Bean, 1988), one possibility is that the MK-801resistant LTD seen in the experiments of Nabavi et al. (2013) is caused by incomplete block of NMDARs. This explanation seems unlikely, however, as we find that LTD is blocked by 2- to 10-fold lower concentrations of MK-801 than those used by Nabavi et al. (2013). Moreover, MK-801 completely prevents the inhibition of synaptic transmission induced by bath application of NMDA (Fig. 1D), suggesting that spontaneous glutamate release produces sufficient levels of receptor activation to enable inhibition of NMDARs during prolonged exposures to MK-801. An alternative, albeit unlikely, explanation is that even if NMDARmediated currents and NMDAR-triggered changes in intracellular $\mathrm{Ca}^{2+}$ are undetectable after application of MK-801 (Nabavi et al., 2013), these assays may have been unable to detect very small currents and, more importantly, small increases in $\mathrm{Ca}^{2+}$ levels at the intracellular mouths of the NMDAR channels during LTD induction protocols.

Because our experiments were done using hippocampal slices obtained from mice whereas rat hippocampal slices were used in the previous studies (Nabavi et al., 2013), another possibility is that the role of metabotropic NMDAR signaling in LTD is species dependent. It would be surprising, however, if such a fundamental property of LTD induction was so different in two closely related species. Moreover, previous findings have shown that
MK-801 not only inhibits LTD in the mouse visual cortex (Crozier et al., 2007) but also blocks LFS-induced LTD and chem-LTD in the CA1 region of rat hippocampus (Raymond et al., 2003; Kollen et al., 2008). Our observation that MK-801 blocks NMDA-induced activation of p38-MAPK also contradicts the role of metabotropic NMDAR signaling in LTD induction (Nabavi et al., 2013), but it is consistent with previous studies showing that MK-801 inhibits NMDA-induced increases in p38MAPK phosphorylation in hippocampal neurons (Waxman and Lynch, 2005; Xiao et al., 2011).

The ability of MK-801 to inhibit LTD induction is consistent with a number of previous findings suggesting that LTD induction requires ionotropic NMDAR signaling. For example, patterns of synaptic stimulation that normally have no effect on synaptic strength can induce LTD when paired with modest postsynaptic depolarization (Oliet et al., 1997; Ngezahayo et al., 2000) or dendritic spikes (Holthoff et al., 2004). This property of LTD induction can be readily explained by the voltage-dependent $\mathrm{Mg}^{2+}$ block of NMDAR ion channels, but it is difficult to understand if LTD induction involves an ion channelindependent form of NMDAR signaling. In addition, LTD is blocked by postsynaptic infusions of $\mathrm{Ca}^{2+}$ chelators (Bröcher et al., 1992; Mulkey and Malenka, 1992; Debanne et al., 1994) and is dependent on $\mathrm{Ca}^{2+}$-activated signaling mechanisms, such as activation of protein phosphatase 2B (Mulkey et al., 1994) and the neuronal $\mathrm{Ca}^{2+}$ sensor hippocalcin (Palmer et al., 2005). Although the mechanism underlying the block of LTD by $\mathrm{Ca}^{2+}$ chelators has been questioned (Nabavi et al., 2013), it is unclear how a $\mathrm{Ca}^{2+}$-independent form of NMDAR signaling could account for the key role of $\mathrm{Ca}^{2+}$-dependent signaling pathways in LTD. Indeed, activation of voltage-dependent $\mathrm{Ca}^{2+}$ channels alone can induce a form of LTD that occludes NMDAR-triggered LTD (Cummings et al., 1996), and the induction of LTD by LFS occludes the persistent depression of synaptic transmission induced by photolysis of caged $\mathrm{Ca}^{2+}$ chelators (Neveu and Zucker, 1996). Thus, our results are consistent with a large body of previous results, all of which support a crucial role for NMDARmediated $\mathrm{Ca}^{2+}$ signaling in LTD. Although our results do not rule out the possibility that NMDARs are capable of metabotropic signaling, they do indicate that this form of signaling is unlikely to have an important role in NMDAR-dependent LTD at excitatory synapses on hippocampal CA1 pyramidal neurons.

\section{References}

Bröcher S, Artola A, Singer W (1992) Intracellular injection of $\mathrm{Ca}^{2+}$ chelators blocks induction of long-term depression in rat visual cortex. Proc Natl Acad Sci U S A 89:123-127. CrossRef Medline

Chen X, Lin R, Chang L, Xu S, Wei X, Zhang J, Wang C, Anwyl R, Wang Q (2013) Enhancement of long-term depression by soluble amyloid $\beta$ protein in rat hippocampus is mediated by metabotropic glutamate receptor and involves activation of p38MAPK, STEP and caspase-3. Neuroscience 253:435-443. CrossRef Medline

Collingridge GL, Peineau S, Howland JG, Wang YT (2010) Long-term depression in the CNS. Nat Rev Neurosci 11:459-473. CrossRef Medline

Crozier RA, Wang Y, Liu CH, Bear MF (2007) Deprivation-induced synaptic depression by distinct mechanisms in different layers of mouse visual cortex. Proc Natl Acad Sci U S A 104:1383-1388. CrossRef Medline

Cummings JA, Mulkey RM, Nicoll RA, Malenka RC (1996) $\mathrm{Ca}^{2+}$ signaling requirements for long-term depression in the hippocampus. Neuron 16: 825-833. CrossRef Medline

Debanne D, Gähwiler BH, Thompson SM (1994) Asynchronous pre- and postsynaptic activity induces associative long-term depression in area CA1 of the rat hippocampus in vitro. Proc Natl Acad Sci U S A 91:11481152. CrossRef Medline

Delgado JY, Coba M, Anderson CN, Thompson KR, Gray EE, Heusner CL, Martin KC, Grant SG, O’Dell TJ (2007) NMDA receptor activation de- 
phosphorylates AMPA receptor glutamate receptor 1 subunits at threonine 840. J Neurosci 27:13210-13221. CrossRef Medline

Dudek SM, Bear MF (1992) Homosynaptic long-term depression in area CA1 of hippocampus and effects of N-methyl-D-aspartate receptor blockade. Proc Natl Acad Sci U S A 89:4363-4367. CrossRef Medline

Holthoff K, Kovalchuk Y, Yuste R, Konnerth A (2004) Single-shock LTD by local dendritic spikes in pyramidal neurons of mouse visual cortex. J Physiol 560:27-36. CrossRef Medline

Huettner JE, Bean BP (1988) Block of N-methyl-D-aspartate-activated current by the anticonvulsant MK-801: selective binding to open channels. Proc Natl Acad Sci U S A 85:1307-1311. CrossRef Medline

Husi H, Ward MA, Choudhary JS, Blackstock WP, Grant SG (2000) Proteomic analysis of NMDA receptor-adhesion protein signaling complexes. Nat Neurosci 3:661-669. CrossRef Medline

Kessels HW, Nabavi S, Malinow R (2013) Metabotropic NMDA receptor function is required for $\beta$-amyloid-induced synaptic depression. Proc Natl Acad Sci U S A 110:4033-4038. CrossRef Medline

Kollen M, Dutar P, Jouvenceau A (2008) The magnitude of hippocampal long term depression depends on the synaptic location of activated NR2containing N-methyl-D-aspartate receptors. Neuroscience 154:13081317. CrossRef Medline

Lee HK, Kameyama K, Huganir RL, Bear MF (1998) NMDA induces longterm synaptic depression and dephosphorylation of the GluR1 subunit of AMPA receptors in hippocampus. Neuron 21:1151-1162. CrossRef Medline

Lee HK, Barbarosie M, Kameyama K, Bear MF, Huganir RL (2000) Regulation of distinct AMPA receptor phosphorylation sites during bidirectional synaptic plasticity. Nature 405:955-959. CrossRef Medline

Lerma J, Marques JM (2013) Kainate receptors in health and disease. Neuron 80:292-311. CrossRef Medline

Li S, Jin M, Koeglsperger T, Shepardson NE, Shankar GM, Selkoe DJ (2011) Soluble $\mathrm{A} \beta$ oligomers inhibit long-term potentiation through a mechanism involving excessive activation of extrasynaptic NR2B-containing NMDA receptors. J Neurosci 31:6627-6638. CrossRef Medline

Lüscher C, Malenka RC (2012) NMDA receptor-dependent long-term potentiation and long-term depression (LTP/LTD). Cold Spring Harb Perspect Biol 4:pii:a005710. CrossRef Medline

Mulkey RM, Malenka RC (1992) Mechanisms underlying induction of homosynaptic long-term depression in area CA1 of the hippocampus. Neuron 9:967-975. CrossRef Medline

Mulkey RM, Endo S, Shenolikar S, Malenka RC (1994) Involvement of a calcineurin/inhibitor-1 phosphatase cascade in hippocampal long-term depression. Nature 369:486-488. CrossRef Medline

Nabavi S, Kessels HW, Alfonso S, Aow J, Fox R, Malinow R (2013) Metabotropic NMDA receptor function is required for NMDA receptor- dependent long-term depression. Proc Natl Acad Sci U S A 110:40274032. CrossRef Medline

Neveu D, Zucker RS (1996) Postsynaptic levels of $\left[\mathrm{Ca}^{2+}\right]_{\mathrm{i}}$ needed to trigger LTD and LTP. Neuron 16:619-629. CrossRef Medline

Ngezahayo A, Schachner M, Artola A (2000) Synaptic activity modulates the induction of bidirectional synaptic changes in adult mouse hippocampus. J Neurosci 20:2451-2458. Medline

Norris CM, Korol DL, Foster TC (1996) Increased susceptibility to induction of long-term depression and long-term potentiation reversal during aging. J Neurosci 16:5382-5392. Medline

Oliet SH, Malenka RC, Nicoll RA (1997) Two distinct forms of long-term depression coexist in CA1 hippocampal pyramidal cells. Neuron 18:969_ 982. CrossRef Medline

Palmer CL, Lim W, Hastie PG, Toward M, Korolchuk VI, Burbidge SA, Banting G, Collingridge GL, Isaac JT, Henley JM (2005) Hippocalcin functions as a calcium sensor in hippocampal LTD. Neuron 47:487-494. CrossRef Medline

Paoletti P, Bellone C, Zhou Q (2013) NMDA receptor subunit diversity: impact on receptor properties, synaptic plasticity and disease. Nat Rev Neurosci 14:383-400. CrossRef Medline

Raymond CR, Ireland DR, Abraham WC (2003) NMDA receptor regulation by amyloid-beta does not account for its inhibition of LTP in rat hippocampus. Brain Res 968:263-272. CrossRef Medline

Tamburri A, Dudilot A, Licea S, Bourgeois C, Boehm J (2013) NMDAreceptor activation but not ion flux is required for amyloid-beta induced synaptic depression. PLoS One 8:e65350. CrossRef Medline

Vissel B, Krupp JJ, Heinemann SF, Westbrook GL (2001) A use-dependent tyrosine dephosphorylation of NMDA receptors is independent of ion flux. Nat Neurosci 4:587-596. CrossRef Medline

Waxman EA, Lynch DR (2005) N-methyl-D-aspartate receptor subtype mediated bidirectional control of p38 mitogen-activated protein kinase. J Biol Chem 280:29322-29333. CrossRef Medline

Xiao L, Hu C, Feng C, Chen Y (2011) Switching of N-methyl-D-aspartate (NMDA) receptor-favorite intracellular signal pathways from ERK1/2 protein to p38 mitogen-activated protein kinase leads to developmental changes in NMDA neurotoxicity. J Biol Chem 286:20175-20193. CrossRef Medline

Yang L, Mao L, Tang Q, Samdani S, Liu Z, Wang JQ (2004) A novel Ca ${ }^{2+}$ independent signaling pathway to extracellular signal-regulated protein kinase by coactivation of NMDA receptors and metabotropic glutamate receptor 5 in neurons. J Neurosci 24:10846-10857. CrossRef Medline

Zhu JJ, Qin Y, Zhao M, Van Aelst L, Malinow R (2002) Ras and Rap control AMPA receptor trafficking during synaptic plasticity. Cell 110:443-455. CrossRef Medline 